Geosistemy perehodnykh zon = Geosystems of Transition Zones $/$ Геосистемы переходных зон

Content is available under the Creative Commons Attribution 4.0 International License (CC BY 4.0)

2020, vol. 4, No. 4, pp. 506-513

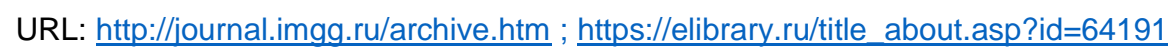

https://doi.org/10.30730/gtrz.2020.4.4.506-513

\title{
The largest lakes of the Kuril Islands: morphometry and geographical distribution (materials for the database)
}

Dmitry N. Kozlov

Institute of Marine Geology and Geophysics, FEB RAS, Yuzhno-Sakhalinsk, Russia

*E-mail: kozlovdn@bk.ru

\section{Abstract PDF ENG Резюме PDF RUS $\quad$ Full text PDF RUS}

Abstract. The work presents modern data on the location, morphometry, and genesis of the largest lakes basins of the Kuril Islands obtained in the volcanological expeditions of the IMGG FEB RAS during 2005-2018 and using open geographic information resources. 1099 lakes were sampled according to the criterion $S \geq 1 \mathrm{~km}^{2}$, the list of studied objects included 20 reservoirs, represented by 7 volcanic and 13 lagoon lakes. The considered lakes are clearly divided according to their origin, area and height of the mirror, and maximum depth. The most part of large lakes falls on the Southern Kurils, and the largest water body - the volcanic lake Koltsevoe - is located on Onekotan Island, which is a part of the group of the Northern Kurils. Volcanic lakes occupy an area of $48.26 \mathrm{~km}^{2}$ ( $60 \%$ of the total area of 20 lakes), the depth varies in the range from several tens to several hundred meters. This category of lakes is characterized by relatively high levels of the mirror, which range from 50 to $648 \mathrm{~m}$ above sea level. Lagoon lakes occupy an area of $32.15 \mathrm{~km}^{2}$ (40\% of the total area of 20 lakes), the depth of water bodies is small - from 1 to $23 \mathrm{~m}$, the absolute height of the lake mirror is from $1-5$ to $8-9 \mathrm{~m}$.

\section{Keywords:}

\section{Kuril Islands, lake, morphometry, lagoon, volcano, caldera}

For citation: Kozlov D.N. The largest lakes of the Kuril Islands: morphometry and geographical distribution (materials for the database). Geosistemy perehodnykh zon = Geosystems of Transition Zones, 2020, vol. 4, no. 4, pp. 506-513. (In Russ., abstr. in Engl.). https://doi.org/10.30730/gtrz.2020.4.4.506-513

Для цитирования: Козлов Д.Н. Самые крупные озера Курильских островов: морфометрия и географическое распределение (материалы к базе данных). Геосистемы переходных зон, 2020, т. 4, № 4, с. 506-513.

https://doi.org/10.30730/gtrz.2020.4.4.506-513

\section{References}

1. Bugaev V.F., Kirichenko V.E. 2008. Nagul'no-nerestovye ozera aziatskoy nerki (vklyuchaya nekotorye drugie vodoemy areala) [Feeding-spawning lakes of Asian sockeye salmon (including some other water bodies of the area)]. PetropavlovskKamchatskiy: Kamchatpress, 280 p.

2. Vereshchagin G.Yu. 1930. Metody morfometricheskoy kharakteristiki ozer [Methods of morphometrical lake characteristic]. Leningrad: Gos. gidrol. in-t [Leningrad: State Hydrological Institute], 115 p. (Trudy Olonetskoy nauchnoy ekspeditsii [Proceedings of Olonetskaya Scientific Expedtition]. Geography; part 2, iss. 1).

3. Gorshkov G.S. 1967. Vulkany Kuril'skoy ostrovnoy dugi [Volcanoes of the Kuril island arc]. Moscow: Nauka, 287 p.

4. Zelenov K.K., Kanakina M.A. 1962. [Biryuzovoe lake (Zavaritskii caldera) and change in its waters chemistry as a result of the 1957 eruption]. Bull. vulkanol. stantsii [Bulletin of volcanological station], 32: 33-44.

5. Ivanov P.V. 1948. Klassifikatsiya ozer mira po velichine i po ikh sredney glubine [Classification of the lakes around the world by size and their average depth]. Bulleten' LGU, 20: 29-36.

6. Kozlov D.N. 2015. [Crater lakes of the Kuril Islands]. Yuzhno-Sakhalinsk: Sakhalin. obl. kraevedch. Muzey [Yuzhno-

Sakhalinsk: Regional Museum of Natural History], In-t morskoy geologii i geofiziki DVO RAN [Institute of Marine Geology and Geophysics FEB RAS], 112 p.

7. Kozlov D.N. 2016. [Morphology of Krasivoe crater lake]. Vestnik KRAUNTs. Nauki o Zemle = Bull. of KRAESC. Earth Sciences, 3(31): 65-71.

8. Kozlov D.N., Degterev A.V., Zarochintsev V.S. Koltsevoe caldera lake: current state and structure of the basin (Onekotan Island, Kuril Islands). Geosistemy perehodnykh zon = Geosystems of Transition Zones, 2(4): 359-364. doi.org/10.30730/25418912.2018.2.4.359-364

9. Korsunskaya G.V. 1958. [The Kuril island arc]. M.: Glavnoye izd-vo geogr. literatury, 222 p.

10. [Kuril Islands]. 2004. Authors: Zlobin T.K., Vysokov M.S., Farkhutdinov I.P. et al. Yuzhno-Sakhalinsk: Sakhalin. Book Publ., $227 \mathrm{p}$.

11. Morfologiya rel'efa [Relief morphology]. 2004. Avtory: Ufimtsev G.F., Timofeev D.A., Simonov Yu.G., Spiridonov A.I., Seliverstov Yu.P., Borsuk O.A., Lastochkin A.N., Rozhdestvenskiy A.P., Loskutov Yu.I., Koshkarev A.V. et al. Moscow: Nauchnyy mir, 184 p. 
12. Muraveyskiy S.D. 1960. Ocherki po teorii i metodam morfometrii ozer [Essays on the theory and methods of lakes morphometry]. In: Reki i ozera. Gidrobiologiya. Stok [Rivers and lakes. Hydrobiology. Flow]. M.: Geografgiz, p. 91-125. 13. Fazlullin S.M., Batoyan V.V. 1989. [Bottom sediments of the crater lake of the Golovnin volcano]. Volcanology and Seismology, 2: 44-55.

14. Fedorchenko V.I. 1962. [Main stages of the postcaldera period of the Golovnin volcano development (Kunashir Island)]. Trudy SakhKNII [Proceedings of SakhKNII], 12: 127-141. 